\title{
Neurotological symptoms and academic performance of university students
}

\author{
Marcia Mattos Marques', Mauricio Malavasi Ganança², \\ Carolina Mattos Marques', Fernando Freitas Ganança ${ }^{3}$. Heloisa Helena Caovilla ${ }^{3}$
}

\begin{abstract}
Objective: To compare the academic performance of university students with or without neurotological symptoms. Method: 100 students enrolled in the Biomedical Sciences Graduate School - Medical Modality of UNIFESP-EPM in 2007 and answered a neurotological screening questionnaire. Results: The symptoms presented once, sometimes, many times or always, in a decreasing order of prevalence, were headache (74.0\%), difficulty with concentration (57.0\%), lack of memory (45.0\%), physical indisposition, nausea /dizziness when in moving vehicle (37.0\%), fainting (27.0\%), nausea (26.0\%), sensation of fullness in the ear (26.0\%), hypersensitivity to sounds (26.0\%), tinnitus (22.0\%), vertigo and other kinds of dizziness (21.0\%), imbalance when walking (21.0\%), difficulty in hearing (21.0\%), imminent sensation of fainting (11.0\%) and vomiting (8.0\%), alone or in different associations; convulsion was not mentioned. The final academic performance score ranged from 5.1 to 10.0. Conclusion: University students with or without neurotological symptoms have manifested similar academic performance.
\end{abstract}

Key words: vestibular diseases/epidemiology, inner ear, vertigo, dizziness, education.

\section{Sintomas otoneurológicos e desempenho acadêmico de estudantes universitários}

\section{RESUMO}

Objetivo: Comparar o rendimento escolar de universitários com e sem sintomas otoneurológicos. Método: Cem alunos matriculados e ativos no Curso de Graduação em Ciências Biomédicas - Modalidade Médica da UNIFESP-EPM em 2007 responderam um questionário de triagem otoneurológica. Resultados: Os sintomas presentes uma vez, algumas vezes, muitas vezes ou sempre, em ordem decrescente de prevalência, foram: dor de cabeça $(74,0 \%)$, dificuldade de concentração $(57,0 \%)$, dificuldade de memória $(45,0 \%)$, mal-estar/enjôo/tontura em veículos em movimento (37,0\%), desmaio (27,0\%), enjôo (26,0\%), sensação de ouvido tapado $(26,0 \%)$, hipersensibilidade a sons $(26,0 \%)$, zumbido $(22,0 \%)$, vertigem ou outros tipos de tontura (21,0\%), desequilíbrio ao andar $(21,0 \%)$, dificuldade para ouvir $(21,0 \%)$, sensação de desmaio iminente $(11,0 \%)$ e vômito $(8,0 \%)$, isoladamente ou em diferentes combinações; convulsão não foi referida. As notas da avaliação final dos alunos foram variáveis entre 5,1 e 10,0. Conclusão: Estudantes universitários com ou sem sintomas otoneurológicos apresentaram rendimento escolar semelhante.

Palavras-chave: doenças vestibulares/epidemiologia, orelha interna, vertigem, tontura, educação.

\section{Correspondence}

Márcia Mattos Marques

Programa de Pós-Graduação

em Neurologia

Rua Pedro de Toledo, 943

04039-002 São Paulo SP - Brasil

E-mail: marcia.mattos@unifesp.br

Received 3 May 2009

Received in final form 12 August 2009

Accepted 14 September 2009
Posture, positional development and an adequate equilibrium facilitate apprehension of space notion, allow a stable body motion, incorporate new perceptions and increase learning possibilities ${ }^{1}$. The difficulty in maintaining orientation, due to a vestibular disorder, impairs spatial and temporal functions, making it impossible to structure the interval notion and sound sequence and restricting school learning development ${ }^{2}$. There are controversies regarding the relationship between cogni- 
tive disorders and vestibular dysfunction. For some authors, decreased memory and concentration might be due to vestibular dysfunction ${ }^{3,4}$, however, other authors could not find any significant correlation between vestibular dysfunction and cognitive impairment and argued that cognitive impairment in patients with vestibulopathy could be due to concomitant affective disorders ${ }^{5}$. A critical review of the literature indicated that lesions of vestibular system may cause posture instability and cognitive dysfunctions, including deficits in attention, learning and memory; also, recent magnetic resonance imaging studies showed atrophy of the hippocampus correlated with the degree of impairment on spatial memory tasks in humans with bilateral vestibular lesions ${ }^{6}$. Two factors seem to explain learning difficulties in children with vestibulopathy: failure to perform coordinated movements and the imprecise concept of the spatial position. These children may position the head in an unusual way when writing, may experience spatial disorientation or distorted sensations of size and the body weight and can cause inability of practicing some physical exercises ${ }^{7}$. Vertigo and other kinds of dizziness of vestibular origin may interfere in the psychological behavior and school performance as well ${ }^{8-}$ ${ }^{10}$. Vestibular dysfunction in childhood may significantly affect communication; low academic performance can be a valuable index of possible labyrinthopathy ${ }^{10}$. Academic deficits, emotional ailment or loneliness, sleep disorders and aversion caused by dizziness impair the individual development ${ }^{11}$. Dizziness is common in both genders, present in more than $10 \%$ of the worldwide population. It may affect children and adolescents but it is more frequent in adults and elderly people. More than $40 \%$ of the adults reported dizziness sometimes in their lives. Chronic dizziness, intermittent or regular, can be mild, moderate or intense, disable or not, causing a variable impact on the individual's quality of life. Imminent fainting or transitory loss of consciousness may occur. Gait abnormalities and falling are common events and may result in severe body traumas. Hearing loss, tinnitus, sensation of fullness in the ear, hypersensitivity to sound, nausea and vomiting might be associated. Due to interactions between vestibular and several areas of the central nervous system, the patient with dizziness usually reports decreased memory and concentration ${ }^{12}$. The prevalent symptoms in children and adolescents with peripheral vestibulopathy were: headache $(84.6 \%)$, dizziness $(84.4 \%)$, behavioral disturbances (84.2\%), motion sickness (77.3\%) and sleep disorders $(77.1 \%)^{13}$.

In children and adolescents with language disorders the neurotological symptoms identified by means of a questionnaire were: decreased concentration $(71.1 \%$ of the cases), memory difficulty (60.5\%), headache (60.5\%), hypersensitivity to sound (34.2\%), motion sickness (26.3\%), hearing loss (26.3\%), difficulty to perform physical exercises or games (23.7\%), fainting (23.7\%), sensation of fullness in the ear (21.0\%), nausea (15.8\%), imbalance (10.5\%) vertigo or dizziness (7.9\%), tinnitus (7.9\%), vomiting $(5.3 \%)$, sensation of imminent fainting (5.3\%) in a decreased order of prevalence ${ }^{14}$.The literature emphasizes that vestibular dysfunction can be a cause or aggravating factor on learning acquisition and development in children. The unknown prevalence of vertigo and balance problems in the university students and the absence of studies on the influence of neurotological symptoms regarding their academic performance motivated this investigation.

The aim of this study is to compare the academic performance of university students with or without neurotological symptoms.

\section{METHOD}

This research was carried out in the Postgraduate Program in Neurology/Neurosciences of the Federal University of São Paulo - Paulista Medical School (UNIFESPEPM) and the Otology and Neurotology Discipline of the Department of Otorhinolaryngology - Head and Neck Surgery of the same University. The project was submitted to the Ethic Committee of the Institution and approved under the number 0834/2007. Written consent was obtained from all the students before enrollment.

This is a transversal descriptive-exploratory study with a quantitative approach performed by only one evaluator. The sample consisted of students of the Biomedical Sciences Graduate School - Medical Modality of UNIFESPEPM, evaluated from April to November of 2007. There was no prior knowledge of the university student's medical history.

The study included effective students regularly enrolled in the Biomedical Sciences Graduate School - Medical Modality of UNIFESP-EPM in 2007 who accepted to take part in the study and answered the questionnaires.

To build the data bank, a neurotological screening questionnaire consisting of 15 short questions on the occurrence of common neurotological symptoms was applied. The students answered a yes/no and how many times: once, sometimes, many times, always questionnaire; it was questioned the presence or not of vertigo or other kinds of dizziness, imbalance when walking, nausea, vomiting, tinnitus, difficulty with hearing, sensation of fullness in the ear, sense of imminent fainting, fainting, convulsion, headache, discomfort/nausea/dizziness when in vehicles in motion, hypersensitivity to sound, decreased memory and concentration.

Vertigo and other kinds of dizziness and imbalance when walking (questions 1 and 2 of the questionnaire) were considered the main neurotological symptoms. The students who positively answered questions 1 and 2 also 
answered the Dizziness Handicap Inventory $(\mathrm{DHI})^{15}$, a quality of life questionnaire translated and validated for the Portuguese language of Brazil ${ }^{16}$. The Dizziness Handicap Inventory consists of 25 questions and evaluates the impact of dizziness in physical, emotional and functional aspects. The possible answers are "yes", "no" and "sometimes"; the affirmative answers score four points, the negative answers did not score, and the "sometimes" answers score 2 points. The total score as well as the specific scores of each aspect were computed considering the arithmetic mean of the points of the aspects. The impact on quality of life was considered mild in the classification of score between 0-30 points, moderate between 31-60 points and severe between $61-100$ points $^{17}$. The greatest score corresponds to 100 points, indicating the maximum damage caused by dizziness and the lower, zero point, revealing no damage due to dizziness.

In the statistical evaluation, descriptive analysis by means of absolute frequencies ( $\mathrm{n}$ ) and relative frequencies (percentage), mean, standard-deviation, minimum and maximum values were applied to the following tests: (1) Chi-square test or Fisher's exact test to study the associations between gender and symptoms; and (2) Friedman test variance analysis to study DHI in relation to emotional, physical and functional scores. Statistical tests were interpreted at a 5\% significance level.

\section{RESULTS}

The neurotological screening questionnaire was answered by 100 of 120 university students of the Biomed- ical Sciences Graduate School - Medical Modality of UNIFESP-EPM, with ages ranging from 17 to 27 years (mean 22 years); 63 females and 37 males.

The symptoms reported once, sometimes, many times or always, in a decreasing order of prevalence, were: headache (74.0\%), decreased concentration (57.0\%), memory difficulties (45.0\%); discomfort/nausea/dizziness when in vehicles in motion (37.0\%), fainting (27.0\%), nausea (26.0\%), sensation of fullness in the ear (26.0\%), hypersensitivity to sound (26.0\%), tinnitus (22.0\%), vertigo or other kinds of dizziness (21.0\%), imbalance when walking (21.0\%), decreased hearing (21.0\%), sensation of imminent fainting (11.0\%) and vomiting (8.0\%), alone or in different combinations. Convulsion was not mentioned.

Vertigo or other kinds of dizziness $\left(\chi^{2}=8.61 ; \mathrm{p}=0.033\right)$, nausea $\left(\chi^{2}=12.95 ; \mathrm{p}=0.0003\right)$, headache $\left(\chi^{2}=9.08\right.$; $\mathrm{p}=0.0026)$, nausea/dizziness/discomfort when in vehicles in motion $\left(\chi^{2}=13.90 ; \mathrm{p}=0.002\right)$, memory difficulty $\left(\chi^{2}=16.14 ; \mathrm{p}=0.0001\right)$ and decreased concentration $\left(\chi^{2}=6.49 ; \mathrm{p}=0.0110\right)$ were predominant in females. No significant difference between genders was observed regarding occurrence of other symptoms of the neurotological questionnaire.

Table 1 shows the number and percentage of symptoms of 26 university students with vertigo or other kinds of dizziness and/or imbalance and of 74 without vertigo or other kinds of dizziness and/or imbalance when walking.

Table 2 shows the score variation, mean, arithmetic mean, standard-deviation, median, minimum value and maximum value of total score, physical, emotional and

Table 1. Number and percentage of symptoms in 26 university students with vertigo or other kinds of dizziness or imbalance when walking and in 74 university students without vertigo or imbalance when walking.

\begin{tabular}{|c|c|c|c|c|}
\hline \multirow[b]{2}{*}{ Symptoms } & \multicolumn{2}{|c|}{$\begin{array}{l}\text { In } 26 \text { university students with vertigo or } \\
\text { other kinds of dizziness and/or imbalance }\end{array}$} & \multicolumn{2}{|c|}{$\begin{array}{l}\text { In } 74 \text { university students without vertigo or } \\
\text { other kinds of dizziness and/or imbalance }\end{array}$} \\
\hline & $\mathrm{N}$ & $\%$ & $\mathrm{~N}$ & $\%$ \\
\hline Nausea & 12 & 46.2 & 14 & 18.9 \\
\hline Vomiting & 2 & 7.7 & 6 & 8.1 \\
\hline Tinnitus in the ear & 9 & 34.6 & 13 & 17.6 \\
\hline Hearing loss & 10 & 38.5 & 11 & 14.9 \\
\hline Sensation of fullness in the ear & 8 & 30.8 & 18 & 24.3 \\
\hline Sense of imminent fainting & 8 & 30.8 & 3 & 4.1 \\
\hline Fainting & 12 & 46.2 & 15 & 20.3 \\
\hline Convulsion & 0 & 0.0 & 0 & 0.0 \\
\hline Headache & 22 & 84.6 & 52 & 70.3 \\
\hline $\begin{array}{l}\text { Nausea/dizziness/discomfort } \\
\text { when in vehicle in motion }\end{array}$ & 15 & 57.7 & 22 & 29.7 \\
\hline Hypersensitivity to sound & 17 & 65.4 & 9 & 12.2 \\
\hline Decreased memory & 18 & 69.2 & 27 & 36.5 \\
\hline Decreased concentration & 19 & 73.1 & 38 & 51.4 \\
\hline
\end{tabular}


Table 2. Variation, mean, arithmetic mean, standard-deviation, median, minimum value and maximum total score handicap and physical, emotional and functional aspects of dizziness handicap inventory of 26 university students with vertigo or others kinds of dizziness and/ or imbalance when walking.

\begin{tabular}{|c|c|c|c|c|c|c|c|}
\hline $\begin{array}{l}\text { Dizziness Handicap } \\
\text { Inventory }\end{array}$ & $\begin{array}{c}\text { Score } \\
\text { variation }\end{array}$ & Mean & $\begin{array}{c}\text { Arithmetic } \\
\text { mean }\end{array}$ & $\begin{array}{l}\text { Standard } \\
\text { deviation }\end{array}$ & Median & $\begin{array}{l}\text { Minimum } \\
\text { value }\end{array}$ & $\begin{array}{c}\text { Maximum } \\
\text { value }\end{array}$ \\
\hline $\begin{array}{l}\text { Total score } \\
\text { (25 questions) }\end{array}$ & $0-100$ & 19.00 & 0.76 & 11.56 & 18.00 & 0 & 50 \\
\hline $\begin{array}{l}\text { Physical aspect } \\
\text { (7 questions) }\end{array}$ & $0-28$ & 8.46 & 1.20 & 4.88 & 8.00 & 0 & 18 \\
\hline $\begin{array}{l}\text { Emotional aspect } \\
\text { (9 questions) }\end{array}$ & $0-36$ & 4.15 & 0.46 & 4.66 & 3.00 & 0 & 14 \\
\hline $\begin{array}{l}\text { Functional aspect } \\
\text { (9 questions) }\end{array}$ & $0-36$ & 6.38 & 0.70 & 5.60 & 6.00 & 0 & 22 \\
\hline
\end{tabular}

functional aspects of DHI of 26 students with vertigo or other kinds of dizziness and/or imbalance when walking. It was observed that physical aspect presented the greatest arithmetic mean (1.20), followed by the functional aspect (0.70) and emotional aspect (0.46). The "no" answer was significantly prevalent in relation to the "yes" and "sometimes" answers for the emotional, physical and functional aspects of DHI $(p<0.0001)$. The impact on quality of life of the 26 students with vertigo or other kinds of dizziness and/or imbalance when walking was considered mild in 21 cases (80.8\%) and moderate in five (19.2\%).

All students were approved in the Course of Biomedical Sciences - Medical Modality of UNIFESP-EPM. The score in final evaluation of the 26 students with vertigo or other kinds of dizziness and/or imbalance when walking ranged between 6.7 and 10.0, mean of 8.1. The score in final evaluation of 74 students without vertigo or other kinds of dizziness and/or imbalance when walking varied between 5.1 and 10.0, mean of 8.6.

\section{DISCUSSION}

Headache, decreased concentration, memory difficulty, nausea/dizziness/generalized discomfort when in vehicles in motion, hypersensitivity to sound, sensation of fullness in the ear, tinnitus, hearing loss, imbalance when walking, nausea, vertigo or other kinds of dizziness, fainting, sense of imminent fainting and vomiting were reported alone or in different combinations by the students.

It is worth emphasizing the high number of neurotological symptoms in the students and its relevance, mainly considering that these symptoms were mentioned as occurring sometimes, many times or always. Children and adolescents with language disorders, with ages ranging from four to 18 years also reported similar symptoms ${ }^{14}$ to those of the university students. No reports in the literature were found regarding the occurrence of these symptoms or its relevance in the university students.

It was observed that vertigo and other kinds of diz- ziness, nausea, headache, nausea/dizziness/discomfort when in vehicles in motion, memory difficulties and decreased concentration were more prevalent in female students. Chronic dizziness is a frequent symptom and is two-fold higher in females than in males ${ }^{18}$.

Vertigo or other kinds of dizziness, imbalance when walking, suggestive symptoms of neurotological disorders, were reported by the 26 university students (26.0\%).

Nausea/dizziness/discomfort when in vehicles in motion mentioned by $61.5 \%$ of these students might occur due to impairment of vestibular function. On the other hand, $36.5 \%$ of the other 74 university students $(74 \%)$ without vertigo or other kinds of dizziness and/or imbalance when walking also presented nausea/dizziness/discomfort when in vehicles in motion. This association of symptoms suggests motion sickness, which can be caused by labyrinth hypersensitiveness or by a vestibular disorder ${ }^{19}$.

Tinnitus, sensation of fullness in the ear, hypersensitivity to sound and/or hearing loss occurred in $76.9 \%$ of the university students with vertigo or other kinds of dizziness and/or imbalance when walking and in 43.2\% of the cases without vertigo or other kinds of dizziness and/or imbalance when walking. The concomitant presence of auditory symptoms reinforces the diagnostic hypothesis of labyrinthopathy ${ }^{12}$.

Headache was the most frequent symptom reported. The clinical association between migraine and vestibular symptoms, such as dizziness, motion intolerance and spontaneous attacks of vertigo, is well documented ${ }^{20}$. Headache was also mentioned by the great majority of children and adolescents with peripheral vestibulopathy ${ }^{13}$.

It was observed that the sense of imminent fainting and/or fainting occurred mainly in the students with vertigo or other kinds of dizziness and/or imbalance. A sense of imminent fainting can be reported by patients with vestibular dysfunction ${ }^{2}$.

Concentration and/or memory difficulties were mainly reported in students with vertigo or other kinds of diz- 
ziness and/or imbalance. An association between cognitive and vestibular disorders is possible ${ }^{3,4,6,12}$, but concomitant affective disorders would justify cognitive complaints in patients with vestibulopathy ${ }^{5}$.

The impact on physical, functional and emotional aspects of the quality of life according to the DHI scores was mild in the majority of the students with vertigo and other kinds of dizziness and or imbalance when walking. The physical aspects were the most defeated ones, followed, in decreasing order, by the functional and the emotional aspects. Impairment in quality of life regarding physical, functional and emotional aspects, based on DHI scores, was found in patients with chronic dizziness and peripheral vestibular syndromes ${ }^{21,22}$. Although the structural validity of the DHI is not established, this questionnaire is considered to be the reference in the health-related quality of life in patients with vertigo or dizziness ${ }^{23}$.

All university students were approved in the final evaluation. The academic performance of students with or without vertigo or other kinds of dizziness and/or imbalance when walking was similar, in contrast to what was reported in children ${ }^{8-10}$. It was possible to assume that the university students reached a developmental phase in which neurotological disorders do not interfere with learning. We could not find any reference in the literature to compare our findings in university students.

This study on prevalence of vertigo and other balance disorders did not aim for any specific diagnosis in the university students. Our screening investigation showed a surprising relevant report of neurotological symptoms in university students. Even considering that the academic performance was similar in students with and without neurotological symptoms, a medical and neurotological evaluation is mandatory to enlighten the diagnosis and pertinent therapeutic orientation. Further studies will be necessary to evaluate the influence of neurotological symptoms on the academic performance of university students.

In conclusion, university students with or without neurotological symptoms have manifested similar academic performance.

\section{REFERENCES}

1. Quirós JB, Schrager OL. Lenguage, aprendizage y psicomotricidad. Buenos Aires: Médica Panamericana; 1987.

2. Stambak M, Jaksic S. Épreuves de niveau et de style moteur. Neuchâtel: Delachaux et Niestlé; 1965.

3. Erikson K. Cognitive aspects of vestibular disorders. Vestibular Disorders Association Newsletter 1989; December 15: Transcript T-3.

4. Eberlein T. Tired? Dizzy? CanÅft concentrate: solving a hidden health problem. Family Circle 1994;20:160-162.

5. Gizzi M, Zlotnick M, Cicerone K, Riley E. Vestibular disease and cognitive dysfunction: no evidence for a causal connection. J Head Trauma Rehabil 2003;18:398-407.

6. Smith PF, Zheng Y, Horii A, Darlington CL. Does vestibular damage cause cognitive dysfunction in humans? J Vestib Res 2005;15:1-9.

7. Mc Hugh HE. Auditory and vestibular disorders in children. Laryngoscope 1962;72:555-565.

8. Ayres AJ. Learning disabilities and the vestibular system. J Learn Disabil 1978;11:18-29.

9. Ganança MM, Caovilla HH. Correlação entre distúrbios de linguagem e disfunção labiríntica. Pediatria Moderna 1990;25:128-145.

10. Campos MI, Ganança FF, Caovilla HH, Ganança MM. Prevalência de sinais de disfunção vestibulares em crianças com vertigem e/ou outros tipos de tontura. Rev Bras Med Otorrinolaringol 1996;3:1165-1170.

11. Medeiros IRT, Bittar RSM, Pedalini MEN, Lorenzi MC, Kii MA, Formigoni LG. Avaliação do tratamento dos distúrbios vestibulares na criança através da posturografia dinâmica computadorizada: resultados preliminares. J Pediatr 2003;4:337-342.

12. Ganança MM, Caovilla HH. Desequilíbrio e reequilíbrio. In: Ganança MM (Ed). Vertigem tem cura? São Paulo: Lemos 1998:13-19.

13. Formigoni LG, Medeiros IRT, Santoro PP, Bittar RSM, Bottino MA. Avaliação clínica das vestibulopatias na infância. Rev Bras Otorrinolaringol 1999;65:78-82.

14. Deus LHR, Ganança CF, Ganança FF, Ganança MM, Caovilla HH. Sintomas otoneurológicos em crianças e adolescentes com distúrbios de linguagem. Acta ORL/Técn Otorrinolaringol 2008;26:118-123.

15. Jacobson GP, Newman CW. The development of the Dizziness Handicap Inventory. Arch Otolaryngol Head Neck Surg 1990;116:424-427.

16. Castro ASO, Gazzola JM, Natour J, Ganança FF. Versão brasileira do Dizziness Handicap Inventory. Pró-Fono Rev Atualiz Cient 2007;19:97-104.

17. Whitney SL, Wrisley DM, Brown KE, Furman JM. Is perception of handicap related to functional performance in persons with vestibular dysfunction? Otol Neurotol 2004;25:139-143.

18. Odman M, Maire R. Chronic subjective dizziness. Acta Otolaryngol 2008;128: 1085-1088.

19. Ganança MM, Caovilla HH, Ganança FF, Ganança CF. Prevenção e controle da cinetose com cinarizina e domperidona. Acta AWHO 2000;19:172-179.

20. Brantberg K, Trees N, Baloh RW. Migraine-associated vertigo. Acta Otolaryngol 2005;125:276-279.

21. Ganança FF, Castro ASO, Branco FC, Natour J. Interferência da tontura na qualidade de vida de pacientes com síndrome vestibular periférica. Rev Bras Otorrinolaringol 2004;70:94-101.

22. Moreira DA, Bohlsen YA, Momensohn-Santos TM, Cherubini AA. Estudo do handicap em pacientes com queixa de tontura, associada ou não ao sintoma zumbido. Arq Int Otorrinolaringol 2006;10:270-277.

23. Duracinsky M, Mosnier I, Bouccara D, Sterkers O, Chassany O. Literature review of questionnaires assessing vertigo and dizziness, a their impact on patients' quality of life. Value Health 2007;10:273-284. 